\title{
Analysis of Electronic Word of Mouth (e-WOM) and Marketing Mix (7P) on Young Consumer Buying Interest in Restaurants and Cafes in Gading Serpong, Tangerang
}

\author{
Tri Djoko Sulistiyo ${ }^{1}$ and Jason Augustian $\mathrm{F}^{2}$ \\ ${ }^{1,2}$ Sekolah Tinggi Pariwisata Trisakti, Jakarta, Indonesia \\ Email: ${ }^{1}$ tridjoko@stptrisakti.ac.id
}

\begin{abstract}
Culinary business competition in Indonesia is getting tougher in this digital era, where consumers have the power to influence other consumer behavior through social media reviews. In addition, one of the main things that affect consumer behavior is the existing marketing mix such as Product, Price, Place, Promotion, People, Process, and Physical Evidence. This study was conducted with the aim of knowing the effect of electronic word of mouth in social media (X1), marketing mix (7P) (X2), and buying interest of young consumer (Y). From the results of this study can be concluded that electronic word of mouth (X1) and marketing mix (7P) (X2) affect the buying interest of young consumers (Y) either partially or simultaneously. From the results of discussion of each variable is not found the variable $X$ that affects variable $Y$ greater than $60 \%$ so it can be concluded that there are many other variables that can affect consumer buying interest. So it is advisable for businesses to be able to pay attention to all aspects related to their business in order to facilitate consumers in choosing.
\end{abstract}

Keywords- Electronic Word of Mouth (e-WOM), Marketing Mix (7P), Buying Interest of Young Consumer.

\section{INTRODUCTION}

\section{A. Background}

Tourism in Indonesia has always been one of the main priorities of economic development policies in every year. It began to be realized because the country's income from tourism in Indonesia every year has increased significantly. According to data from BPS and Pusdatin in 2015, the number of foreign tourist arrivals in 2015 through 19 main entrances of Indonesia is a number of 9,729,350 visitors, an increase of 293,939 visitors from 2014 and always increased.

One component in the tourism industry is the culinary field. Indonesia is known as a country that has a wealth of amazing culinary. One of the attractions is the motivation of domestic and foreign tourists. Culinary business in Indonesia has developed so rapidly every year. It also can not be separated from the emergence of consumer needs to obtain different food and with the broad tastes. The demand appears to trigger entrepreneurship in the culinary field with a variety of concepts and characters. It certainly requires every entrepreneur to get the market as much as possible because of the very tight competition between each other.

Based on the business competition, it is even harder to remember that people have entered the digital era. The era of information society in Indonesia is shown by the rapid development of Information and Communication Technology (ICT), especially the telecommunication industry over the past few years. Therefore in Indonesia, currently known the term "Digital Economy" which penetrated in urban and rural areas in Indonesia.

The easiness to find information in this digital era that culinary entrepreneurs are used to promote their business via the internet. There are many ways that entrepreneurs can attract the consumers, one of the ways is by encouraging consumers who have felt their products to write comments on social media or internet. According to the data from Internet World Stats shows that internet users in Indonesia in 2016 is 132.7 million people, both accessed via computer or mobile phone. This number is increasing drastically from 45 million in 2011 and 78 million in 2015. The possibility of internet growth is not separated by the growing use of social media that much in demand by internet users. 
With the development of internet technology, companies are increasingly benefited. Companies can take advantage of the customer's interactive community to start a dialogue with their customers. They can build networks to create a good electronic word of mouth (e-WOM) on their market offerings.

The appearance of a new trend called Social Web, consumers can see the good of a product easily only through the opinions that given by the consumers who write their experience in social media. But it can also raise awareness of potential customers for the products available. This is what makes consumers will be easier in making purchases.

In addition to opinions and reviews about these products, consumers also see other factors. The factor is the marketing mix. In a tourism business generally pay attention to 7 (seven) indicators of marketing mix, including, Product, Price, Place / Distribution, Promotion, People (Process), Process (process) and Physical Evidence (physical evidence). This in addition to being an important focus of the business is also a few factors that consumers consider before making a purchase decision. In addition to opinions and reviews about these products, consumers also see other factors. The factor is the marketing mix. In a tourism business generally pay attention to 7 (seven) indicators of marketing mix, including, Product, Price, Place / Distribution, Promotion, People (Process), Process (process) and Physical Evidence (physical evidence). This in addition to being an important focus of the business is also a few factors that consumers consider before making a purchase decision.

The diversity of available product providers does not guarantee that all product providers will receive the same number of customers. In one area that has a diversity of culinary business, every business that has its own uniqueness generally has the opportunity to get more number of consumers. But this can be broken with a variety of factors that affect consumer buying interest.

Tangerang Selatan is one of the most developed areas in Jabodetabek (Jakarta, Bogor, Depok, Tangerang, Bekasi), especially in the development of restaurant and cafe industries. This development is most visible one of them in North Serpong more precisely Gading Serpong region. Evidenced by the number of restaurants and cafes that appear in the last 2 years. The large selection of restaurants and cafes is making some consumers trying to find related information before making sure their decision to choose the right place. The information gained varies, ranging from reviews of the venue to the recommendations and experiences of previous customers.

\section{B. Problem Identification}

The number of restaurants and cafes that have sprung up makes a lot of problems that arise related to it. Problems that arise a lot related to how the influence of electronic word of mouth and marketing mix of consumer buying interest and how big the influence of these two factors.

\section{Problem Limitation}

From the overall problem, in this study the problem is limited as follows, this research is aimed at consumers around 17-25 years who ever find out the information about restaurant or cafe in Gading Serpong area and live in Jabodetabek area (Jakarta, Bogor, Depok, Tangerang, Bekasi) which in this case is taken from active students of Trisakti Institute of Tourism batch 2013-2016.

\section{Problem formulation}

After making problem limitations, then in this study the problem can be formulated into:

1. How much influence of electronic word of mouth to the buying interest of young consumers in restaurants and cafes in the Gading Serpong area?

2. What is the level of influence of the marketing mix (7P) on the buying interest of young consumers in restaurants and cafes in the Gading Serpong area?

3. How high is the influence of electronic word of mouth and marketing mix (7P) on the buying interest of young consumers in restaurants and cafes in the Gading Serpong area?

4. Which variable is more influential on the interest of buying young consumers in restaurants and cafes in the Gading Serpong area?

\section{E. The main purpose of the Research}

The general purpose of this research are: 
1. To determine the effect of electronic word of mouth on the interest of buying young consumers in restaurants and cafes in the area of Gading Serpong.

2. To determine the effect of marketing mix (7P) on the interest of buying young consumers in restaurants and cafes in the area of Gading Serpong.

3. To determine the effect of electronic word of mouth and marketing mix (7P) on the interest of buying young consumers in restaurants and cafes in the area of Gading Serpong.

4. To find out which variable is more influential on the interest of buying young consumers in restaurants and cafes in the area of Gading Serpong.

\section{LITERATURE REVIEW}

\section{A. Social Media}

The development of social media has an impact on how to communicate in a business or organization. The appearance of Web 2.0 allows people to build business and social relationships and share information. With the rapid development of the digital world and a high awareness of the latest information makes social media very popular. Marketing through social media typically focuses on creating content that attracts attention and encourages readers to share with their social networks. Social media becomes a platform that is easily accessible to anyone, then the company's opportunity to increase their brand awareness and facilitate conversations with customers. The features in the web now make it easy for everyone to create and most importantly disseminate their own content. Post on blogs or Instagram, update status on Facebook or videos on YouTube can be reproduced and viewed by millions of people for free. Social media is already designed to facilitate social interaction that is interactive or two-way. Internet-based social media that changes the pattern of information dissemination from one to many audiences becomes a large audience to many audiences (Paramitha, 2011: 42).

According to Gunelius (2011: 10) social media is the online publishing and communication tools, sites, and goals of Web 2.0 that are proceed in conversation, engagement, and participation. The definition of expanded social media says that social media is the democratization of information, changing people from content readers to content publishers. This is a shift from broadcast mechanism to many to many models, proceed in conversations between writers, people, and peers.

According to Philip Kotler and Kevin Keller (2012: 568), social media is a means for consumers to share text, image, audio and video information with each other and with companies. Meanwhile, according to Hendri, Muhammad Yusup, Yuliana Isma Graha (2007: 2) in Nurfitriani and Rumyeni (2016: 4), social media are social networking sites such as web-based services that allow individuals to build public or semi public profiles in a restricted system, other users with whom they connect and view and browse the list of connections they made by others with a system. To facilitate sales promotion companies now prefer a practical way, one of them using social media. Social media has various forms and purposes of use. Some types of social media applications according to Puntoadi (2011: 34) are:

1. Bookmarking

Sharing website addresses that users think bookmark sharing interest them. Social bookmarking provides an opportunity to divide as a link and tags they are interested in, it is aiming for more people to enjoy what we like. Some examples of bookmarking sites are www.dig.com, www.muti.com, www.reddit.com.

2. Content Sharing

Through the content of sharing websites, people create various media and publish it for the purpose of sharing to others. YouTube and Flickr is a content sharing site frequented by audiences. Youtube provides facilities for people who want to share videos from YouTube to website or blog, as well as Flickr provide an opportunity to be able to print out various images from Flickr.

3. Wiki

Social media often provides all the information presented by site visitors themselves and audiences can do editing if felt the information submitted is incorrect, incorrect, or incomplete. Some sites Wikis have different characteristics like Wikipedia is a knowledge 
sharing site, focusing in Wikitravel place information, and some also embrace the concept of community more exclusive.

4. Flickr

Sites belonging to yahoo that specialize in image sharing with contributors who are experts in the field of photography from around the world. Flickr can be made as "Photo catalog" for the product you want to market.

5. Social network

Activities that use various features provided by a particular site to build relationships, interact with others. Social networking sites are Facebook, MySpace, Linkedin.

6. Creating Opinion

Social media that provides the means to share opinions with others to the whole world. Through the social media creating opinion, everyone can write, journalist and commentator. Blog is a website that has properties creating-opinion. According to Philip Kotler and Kevin Keller (2012: 568-570), there are three main platforms for social media:

a) Online Communities and Forums

Online communities and forums come in all shapes and sizes. Many of them made by a customer or group of customers without commercial interest or affiliate company. Some are sponsored by companies that are members communicate with companies and with each other through posts, instant messaging and chat discussions about related special interests with company and brand products

b) Blogs

There are three million of blog users and they vary greatly, some are personal to close friends and family, others are designed to reach and affect a wide audience.

c) Social Networks

Social networks have become an important thing both in business to consumer and business to business marketing such us Facebook, Twitter, Instagram. Different networks offer different benefits to the company.

\section{B. Social Media Marketing}

Social media marketing or often called social media marketing is a form of direct or indirect marketing that is used to build awareness, recognition, recall, and action for brands, businesses, products, people, or other entities and is done using the tools of the social Web , such as sharing blogging, microblogging, social networking, social bookmarking, and content (Gunelius, 2011: 10). Social media marketing includes certain tactics such as sharing coupons or announcing sales on Facebook or Twitter, or can include a wider build of brand initiatives such as communicating with people or creating compelling content on a blog, in a video uploaded to YouTube or in a shared presentation sharing slides. In addition, social media marketing offers great opportunities for entrepreneurs, small businesses, medium companies, and large corporations to build their brands and their businesses (Gunelius, 2011: 10). According to Gunelius (2011: 15) the most common goal of social media marketing.

1. Building relationships

The main benefit of social media marketing is the ability to build relationships with consumers actively.

2. Build a brand

Conversations via social media present the perfect way to increase brand awareness, improve brand recognition and memories and increase brand loyalty.

3. Publicity

Marketing through social media provides an outlet where companies can share important information and modify negative perceptions.

4. Promotion

Through social media marketing, providing exclusive discounts and opportunities for an audience to make people feel valued and special, and to meet short-term goals. 


\section{Market research}

Use tools from the social web to learn about customers, create demographic profiles and customer behavior, learn about consumer wants and needs, and learn about competitors.

\section{Word of Mouth (WOM)}

WOM or Word of Mouth is the process of passing person-to-person information and plays a major role in WOM or Word of Mouth is the process of passing person-to-person information and playing a leading role in customer purchasing decisions (Richins \& Root-Shaffer, 1988) in Twitter Power: Tweets as Electronic Word of Mouth (Bernard J. Jansen et al., 2009). According to Hasan (2010), word of mouth is a compliment, recommendation and customer comments around their experience of services and products that really affect customer decisions or their buying behavior. Word of mouth can form the trust of customers. Whereas According to Sernovitz (2009), word of mouth is a conversation that naturally occurs between people. Word of mouth is the original consumer talk.

\section{Electronic Word of Mouth (e-WOM)}

With the Internet created a new paradigm in Word of Mouth communication and this is the beginning of the emergence of the term electronic Word of Mouth or e-WOM. e-WOM is now regarded as an evolution of traditional interpersonal communications leading to a new generation of cyberspace. With the advancement of technology more and more consumer trends to busy looking for information needed about a product before they make a purchase, such as through Zomato (review sharing platform), Lazada (online shop), and Kaskus (online community) and this results in e- . Hennig-Thurau et al. (2004) describes e-WOM as "a negative or positive statement made by actual, potential or previous consumer of a product or company where this information is available to people or institutions through the internet". And consumers considering negative WOM information will be more helpful than positive information in distinguishing high quality products and low quality products (Herr et al., 1991).

\section{E. Marketing Mix}

In marketing there is a marketing strategy called marketing mix (Mix) which has an important role in influencing consumers in purchasing a product or service offered by the company. According to Buchari Alma (2007: 130), the marketing mix is a strategy to combine marketing activities, in order to get the maximum combination that leads to satisfactory results. As according to Zeithaml and Bitner (2008: 48) marketing mix is the organizational elements within the company that can be controlled by the company in communication with guests. Meanwhile, according to Kotler and Armstrong (2012: 92) marketing mix is a marketing tool that consists of products, prices, promotions and distributions are collaborated to make something in accordance with market desires.

In the marketing mix there is a set of marketing tools known in 4P terms, namely product (product), price (place), place (place or distribution channel) and promotion (promotion). Things are a little different happening in the service industry. Marketing in the service industry has several additional marketing tools such as people, physical evidence and process, so it is better known as 7P.

\section{F. Consumer Behavior}

After the technical aspects that we have discussed, there are non technical aspects that also have important roles. How to purchase consumers, purchasing decisions, customer satisfaction to consumer loyalty, all that is summed up in consumer behavior. Consumer behavior in outline is an action by consumers ranging from searching, using and valuing goods or services that are considered will satisfy them.

Consumer behavior is a dynamic interaction between individuals and involves the interaction of influence and cognition, behavior and surrounding events and the existence of exchanges between individuals (Peter and Olson, 2010). Schiffman and Kanuk (2008: 6) say that consumer behavior is the study of how a person makes the decision to allocate their resources (time, money, effort, and energy) to consume an item. While Kotler and Keller (2008: 214) mention that consumer behavior is the study of how individuals, groups and organizations choose, buy, use and place goods, services, ideas or experiences to satisfy their wants and needs. 
Consumer behavior is strongly influenced by environmental circumstances and community situations. This means that each consumer must have different judgments, needs, attitudes and tastes, so that every consumer's purchasing decision will be influenced by several factors. According to Kotler (2008: 25), factors that affect consumer behavior consists of 4, namely:

1. Factors Culture

Cultural factors have broad and deep influence on consumer behavior. Cultural factors consist of: culture, subculture, social class,

2. Social Factors

In addition to cultural factors, a consumer's behavior is influenced by social factors such as reference groups, family and social status.

3. Personal Factors

Personal factors that contribute to consumer behavior consist of: age and stage of life cycle, occupation and economic environment, lifestyle, personality and self-concept.

4. Psychological Factors

The choice of purchasing a person is influenced by four main psychological factors namely motivation, perception, learning, and belief and establishment.

\section{G. Buying Interest of Consumer}

The rapid development of technology and the era development, makes the company is required to have the best strategy to attract customers to buy their products. In addition, today's customers are smart and critical customers. They can access various information before deciding to buy a product. They look for information through various way, such as through the internet, asking friends and not believe easily in the words were said by company who are doing the promotion.

According to Fishbein and Ajzen in Chen et. al (2004), interest is a plan or it seems someone will behave in certain situations with a certain way whether someone will do it or not. Beside that, Fishbein and Ajzen also said that there are four different elements in the interest, they are : behavior, the object where the behavior is directed, the situation where the behavior is done and the time where the behavior is done too.

Peter and Olson (2010) mentioned that interest is a plan to engage with specific behavior in purpose to achieve goals. According to Henry Assael (1998), buying interest is a behavior that appears as a response of object or also of repeat purchase. In addition, he also said that buying interest is the last stage of a complex purchasing decision process. This process begins with the appearance of the need for a product or brand ( need arousal) followed by the information processing by consumers ( consumer information processing ). After that, the consumer will evaluate the product or brand. The results of the evaluation will make customer have an intention to buy before they made a purchase. Henry Assael also argues that marketers will always test elements of the marketing mix that may affect buying interest. Schiffman and Kanuk (2008) also define that buying interest as a model of someone's attitude to a very precise item in measuring the attitude of a particular product, service, or brand.

\section{METHODS}

The method used in this research is quantitative descriptive method. According to Sugiyono (2012:8), descriptive research is a study to determine the value of independent variables, either one variable or more without making a comparison or connecting with other variables. Quantitative research method, as said by Sugiyono (2012:8) is a research method based on the positiveism philosophy, used to research the population or a particular sample, data collection using research instruments, quantitative / statistical data analysis, with the purpose to verify the hypothesis that has been decided.

As the conclusion, quantitative descriptive research method is a method of describing and defining, describing phenomenon that is examined systematically, factually and accurately and also defines the effect that occurs from independent variable to dependent variable. And also, regression method will be used to find the influence between each variable. This study will identify the effect of electronic word of mouth in social media and marketing mix (7P) to the buying interest of young consumers. 
The analytical unit of this research is consumers aged 17-25 years old who ever find out / know information about restaurants / cafes in the area of Gading Serpong and live in Jabodetabek (Jakarta, Bogor, Depok, Tangerang, Bekasi) area which in this case will be taken from active students of Trisakti School of Tourism (2013-2016 generation).

\section{IV.RESULT AND DISCUSSION}

\section{A. Demographic Characteristics of Respondents}

Demographic description of respondents to know the number of respondents based on age, domicile area, frequency of using social media, frequency of visits Gading Serpong and interest of respondents visited Gading Serpong. Total respondents who have completed questionnaires that aged 17 - 19 years old are 87 people (26\%), aged 20 - 22 years old are 217 people (64.8\%) and aged $23-25$ years old are 31 people $(9.3 \%)$. So it can be concluded that the age of respondents who are still using social media actively are very diverse.

Total respondents who have filled in questionnaires that live in North Jakarta area are 24 people (7.2\%), West Jakarta area with 50 people (14.9\%), who are live in Central Jakarta are 12 people (3.6\%), who are live in South Jakarta totaled 44 people (13.1\%), East Jakarta area with 9 people (2.7\%), Tangerang area with 83 people $(24.8 \%)$, South Tangerang area with 82 people $(24.5 \%)$, who are live in Bogor area are 15 people (4.5\%), who are live in Depok area amount to 5 people $(1.5 \%)$ and Bekasi area with 11 people (3.3\%). So it can be concluded that the respondents from all areas in Jabodetabek have awareness of information about the object of research.

Total respondents who have completed questionnaires that using social media less than 1 hour in one day are 14 people (4.2\%), 1-2 hours per day are 8 people (2.4\%), 3-4 hours per day are 86 people (25.7\%) and more than 4 hours per day totaled to 227 people $(67.8 \%)$. So it can be concluded that respondents mostly use social media more than 4 hours in a day.

Total respondents who have filled in questionnaires that had never visited the Gading Serpong area are 31 people $(9,3 \%), 1$ times a week are 89 people (26,6\%), 2 times a week amounted to 97 people (29\%) and more than 2 times amounted to 118 people (35.2\%). So it can be concluded that respondents mostly visit to Gading Serpong more than 2 times a week.

Total respondents who have filled in questionnaire that dont have an interest to visit Gading Serpong are 7 people $(2.1 \%)$, respondent that maybe have some interest to visit Gading Serpong are 75 people $(22.4 \%)$ and 253 people $(75,5 \%)$ interested in visiting. So it can be concluded that respondents mostly have an interest to visit Gading Serpong area after knowing information about Gading Serpong.

\section{B. Result of Validity Test}

From the analysis results obtained the values that exist in the column of corrected item-total correlation show more than 0.1072 . So, it can be concluded that 10 statements concerning variable $\mathrm{X} 1$ are valid. The values that exist in corrected item-total correlation column show more than 0.1072 . So it can be concluded that 27 statements concerning variable X2 are valid. The values that exist in the corrected item-total correlation column show more than 0.1072. So it can be concluded that 335 questionnaires concerning the variable $\mathrm{Y}$ are valid.

\section{Result of Reliability Test}

From the analysis results obtained that Cronbach's Alpha variable X1 is 0.939 . So, it can be concluded that 10 statements concerning variable X1 are very reliable. And for Cronbach's Alpha variable $\mathrm{X} 2$ is 0.983 . It can be concluded that 27 statements concerning the variable $\mathrm{X} 2$ are very reliable. For Cronbach's Alpha variable Y is 0.938. It can be concluded that the 4 statements concerning variable $\mathrm{Y}$ are very reliable. 


\section{Result of Simple Linear Regression Test}

\section{Simple Linear Regression Analysis Variable X1 to Variable Y}

Simple linear regression analysis were used to identify the effect of variable X1 to variable $\mathrm{Y}$. This is the result of a simple linear regression analysis between Electronic Word of Mouth (X1) variable to Buying Interest of Youth Consumer (Y) variable :

TABLE I. RESULT OF DETERMINATION COEFFICIENT ANALYSIS OF VARIABLES X1 TO VARIABLE Y

\begin{tabular}{|c|c|c|c|c|c|c|c|c|c|}
\hline \multicolumn{10}{|c|}{ Model Summary } \\
\hline & & & & & & Change & Statist & & \\
\hline $\begin{array}{c}\text { Model } \\
1\end{array}$ & $\begin{array}{l}\mathrm{R} \\
.673^{\mathrm{a}}\end{array}$ & $\begin{array}{c}\mathrm{R} \\
\text { Square } \\
.453\end{array}$ & $\begin{array}{c}\text { Adjusted } \\
\text { R Square } \\
.451\end{array}$ & $\begin{array}{r}\text { Std. Error of } \\
\text { the Estimate } \\
3.169\end{array}$ & $\begin{array}{c}\text { R Square } \\
\text { Change } \\
.453\end{array}$ & $\begin{array}{c}\text { F } \\
\text { Change } \\
275.409\end{array}$ & df1 & $\begin{array}{c}\text { df2 } \\
333\end{array}$ & $\begin{array}{r}\text { Sig. F } \\
\text { Change } \\
.000\end{array}$ \\
\hline
\end{tabular}

a. Predictors: (Constant), X1_ALL

Source : Result of SPSS 24 Analysis

According to the output, the result of determination coefficient $\left(\mathrm{R}^{2}\right)$ is 0.453 , which means that $45.3 \%$ variable $\mathrm{Y}$ are effected by variables $\mathrm{X} 1$, while $54.7 \%$ are effected by other variables such as Brand Image, Brand Equity, Brand Awareness, Customer Satisfaction, Service Quality, Product Quality, and etc.

TABLE II. RESULT OF COEFFICIENT ANALYSIS OF VARIABLES X1 TO VARIABLE Y

\begin{tabular}{|c|c|c|c|c|c|c|c|c|}
\hline \multicolumn{9}{|c|}{ Coefficients $^{\mathrm{a}}$} \\
\hline & & \multirow{3}{*}{\multicolumn{2}{|c|}{$\begin{array}{l}\text { Unstandardized } \\
\text { Coefficients }\end{array}$}} & Standardize & & & & \\
\hline & & & & & & & \multirow{2}{*}{\multicolumn{2}{|c|}{$\begin{array}{l}\text { 95.0\% Confidence } \\
\text { Interval for B }\end{array}$}} \\
\hline & & & & Coefficients & & & & \\
\hline & & & & & & & Lower & Upper \\
\hline \multicolumn{2}{|r|}{ Model } & & Std. Error & Beta & $\mathrm{t}$ & Sig. & Bound & Bound \\
\hline 1 & (Constant) & 3.753 & .861 & & 4.359 & .000 & 2.060 & 5.447 \\
\hline & X1_ALL & .304 & .018 & .673 & 16.595 & .000 & .268 & .340 \\
\hline
\end{tabular}

a. Dependent Variable: Y_ALL

Source : Result of SPSS 24 Analysis

The above table shows a simple linear regression equation between Electronic Word of Mouth (X1) variable to Buying Interest of Consumer $(\mathrm{Y})$ with the following equation:

$$
\mathrm{Y}=3.753+0.304 \mathrm{X}
$$

From the above equation, it can be explained that if Electronic Word of Mouth (X1) is constant or unchanged, so Buying Interest of Consumer (Y) will be 3.753 units. The Electronic Word of Mouth (X1) regression coefficient value is 0.304 , it means that every respondent increase one unit to Electronic Word of Mouth (X1), will increase Buying Interest of Consumer by 0,304. If Electronic Word of Mouth is increasing, it will also increase Buying Interest of Consumers and if the Electronic Word of Mouth is decreasing, it will also decrease Buying Interest of Consumer.

The T-test is conducted to identify the effect of Electronic Word of Mouth (X1) variable to Buying Interest of Consumer $(\mathrm{Y})$ variable. $\mathrm{T}$ test is done by comparing the value of $\mathrm{t}_{\text {count }}$ with $\mathrm{t}_{\text {table }}$. If the $\mathrm{t}_{\text {count }}>\mathrm{t}_{\text {table }}$, it can be stated that Electronic Word of Mouth (X1) variable has an effect to Buying Interest of Consumer (Y) variable. Value of $\mathrm{T}_{\text {table }}$ on $\alpha=0.05$ is 1,967 . It means, that the $\mathrm{t}_{\text {count }}>\mathrm{t}_{\text {table }}$ (16.595> 1.967) so it can be stated that Electronic Word of Mouth (X1) variable has an partial effect to Buying Interest of Consumer (Y) variable.

\section{Simple Linear Regression Analysis Variable X2 to Variable Y}

Here are the result of simple linear regression analysis between Marketing Mix (7P) (X2) variable to Buying Interest of Youth Consumer (Y) variable : 
TABLE III. RESULT OF DETERMINATION COEFFICIENT ANALYSIS OF VARIABLES X2 TO VARIABLE Y

\begin{tabular}{|c|c|c|c|c|c|c|c|c|c|}
\hline \multicolumn{10}{|c|}{ Model Summary } \\
\hline & \multirow[b]{3}{*}{$\begin{array}{l}\mathrm{R} \\
.771^{\mathrm{a}}\end{array}$} & \multirow{3}{*}{$\begin{array}{c}\mathrm{R} \\
\text { Square } \\
.595\end{array}$} & \multirow{2}{*}{$\begin{array}{l}\text { Adjusted } \\
\text { R Square }\end{array}$} & \multirow{2}{*}{$\begin{array}{l}\text { Std. Error of } \\
\text { the Estimate }\end{array}$} & \multicolumn{5}{|c|}{ Change Statistics } \\
\hline & & & & & R Square & & & & Sig. F \\
\hline $\begin{array}{c}\text { Model } \\
1\end{array}$ & & & $\begin{array}{r}\text { R Square } \\
.593\end{array}$ & $\begin{array}{r}\text { the Estimate } \\
2.727\end{array}$ & $\begin{array}{r}\text { Change } \\
.595\end{array}$ & $\begin{array}{l}\text { Change } \\
488.367\end{array}$ & dt1 & $\begin{array}{c}\text { df2 } \\
333\end{array}$ & $\begin{array}{r}\text { Change } \\
000\end{array}$ \\
\hline
\end{tabular}

a. Predictors: (Constant), X1_ALL

Source : Result of SPSS 24 Analysis

According to the output, the result of determination coefficient $\left(\mathrm{R}^{2}\right)$ is 0.595 , which means that $59.5 \%$ variable $\mathrm{Y}$ are effected by variables $\mathrm{X} 2$, while $40.5 \%$ are effected by other variables such as Brand Image, Brand Equity, Brand Awareness, Customer Satisfaction, Service Quality, Product Quality, and etc.

From the result of the same analysis also obtained the effected value of each sub-variable $\mathrm{X} 2$ to $\mathrm{Y}$ partially. Determination coefficient value $\left(\mathrm{R}^{2}\right)$ of each sub-variables effect can be seen in table 4.19 as follows :

TABLE IV. RESULT OF COEFFICIENT DETERMINATION ANALYSIS SUB-VARIABLE X2 TO VARIABLE Y

\begin{tabular}{cc}
\hline SUB-VARIABLE (X2) & $\begin{array}{c}\text { DETERMINATION } \\
\text { COEFFICIENT VALUE }\end{array}$ \\
\hline Product & 0.441 \\
Price & 0.379 \\
Place & 0.473 \\
Promotion & 0.468 \\
People & 0.530 \\
Process & 0.484 \\
Physical Evidence & 0.661 \\
\hline
\end{tabular}

Above showed that among 7 of sub-variable X2, the highest effected value is Physical Evidence with total 0.661 or $66.1 \%$ while the lowest is owned by Price with total 0.379 or $37.9 \%$. It proves, that the product being offered more attract consumer's buying interest than the other sub-variables.

TABLE V. RESULTS ANALYSIS OF VARIABLE COEFFICIENT X2 ON VARIABLE

\begin{tabular}{|c|c|c|c|c|c|c|c|c|}
\hline \multicolumn{9}{|c|}{ Coefficients $^{\mathrm{a}}$} \\
\hline \multirow{4}{*}{\multicolumn{2}{|c|}{ Model }} & \multirow{2}{*}{\multicolumn{2}{|c|}{$\begin{array}{l}\text { Unstandardized } \\
\text { Coefficients }\end{array}$}} & \multirow{2}{*}{\multicolumn{3}{|c|}{$\begin{array}{l}\text { Standardize } \\
\mathrm{d} \\
\text { Coefficients }\end{array}$}} & \multirow{2}{*}{\multicolumn{2}{|c|}{$\begin{array}{l}95.0 \% \text { Confidence } \\
\text { Interval for B }\end{array}$}} \\
\hline & & & & & & & & \\
\hline & & & & & & & Lower & Upper \\
\hline & & B & Std. Error & Beta & $\mathrm{t}$ & Sig. & Bound & Bound \\
\hline 1 & (Constant) & 1.295 & .759 & & 1.706 & .089 & -.198 & 2.789 \\
\hline & X1 ALL & .136 & .006 & .771 & 22.099 & .000 & .124 & .148 \\
\hline
\end{tabular}

Source: SPSS Processed Results 24

The above table shows a simple linear regression equation between the Marketing Mix (7P) (X2) variable on Consumer Buy (Y) Interest with the following equation:

$$
\mathrm{Y}=1,295+0.136 \mathrm{X}
$$

From the above equation, it can be explained that if the Marketing Mix (7P) (X2) is constant or unchanged, then the Consumer Buy Interest (Y) created is 1,295 units. The value of regression coefficient of Marketing Mix (7P) (X2) is 0.136 , it indicates that every increase of one respondent's 
unit to Marketing Mix (7P) (X2) will increase Consumer Buying Interest by 0.136. If the Marketing Mix (7P) increases, it will increase consumer buying interest and if the Marketing Mix (7P) decreases it will decrease Consumer Buying Interest. $\mathrm{T}$ test is done to know the influence between marketing mix variable (7P) $(\mathrm{X} 2)$ to consumer buying interest variable $(\mathrm{Y})$. Test $\mathrm{t}$ is done by comparing the

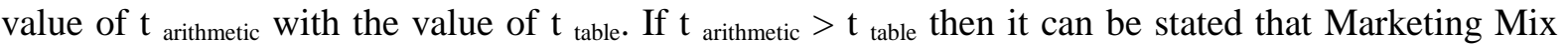
(7P) (X2) has an influence on consumer buying interest variable (Y). The value of $t_{\text {table }}$ at $\alpha=0.05$ is 1.967. This shows that $\mathrm{t}_{\text {arithmetic }}>\mathrm{t}_{\text {table }}(22,099>1,967)$ so it can be stated that Marketing Mix (7P) (X2) has partial influence to Consumer Buy Interest (Y).

\section{Multiple Linear Regression Analysis}

TABLE VI. RESULTS OF DETERMINATION COEFFICIENT ANALYSIS VARIABLES X1 AND X2 TO VARIABLE Y

\begin{tabular}{|c|c|c|c|c|c|c|c|c|c|}
\hline \multicolumn{10}{|c|}{ Model Summary $^{\mathbf{b}}$} \\
\hline \multirow[b]{2}{*}{ Model } & \multirow{3}{*}{$\begin{array}{l}\mathrm{R} \\
.783^{\mathrm{a}}\end{array}$} & \multirow{3}{*}{$\begin{array}{r}\text { R Square } \\
.614\end{array}$} & \multirow[b]{2}{*}{$\begin{array}{l}\text { Adjusted } \\
\text { R Square }\end{array}$} & \multirow[b]{2}{*}{$\begin{array}{l}\text { Std. Error } \\
\text { of the } \\
\text { Estimate }\end{array}$} & \multirow[b]{2}{*}{$\begin{array}{c}\mathrm{R} \\
\text { Square } \\
\text { Change }\end{array}$} & \multicolumn{3}{|c|}{ Change Statistics } & \multirow[b]{2}{*}{$\begin{array}{l}\text { Sig. F } \\
\text { Change }\end{array}$} \\
\hline & & & & & & $\begin{array}{c}\mathrm{F} \\
\text { Change }\end{array}$ & df1 & $\mathrm{df} 2$ & \\
\hline 1 & & & .612 & 2.666 & .614 & $\begin{array}{r}263.86 \\
1\end{array}$ & 2 & 332 & .000 \\
\hline
\end{tabular}

a. Predictors: (Constant), X2_ALL, X1_ALL

b. Dependent Variable: Y_ALL

\section{Source: SPSS Processed Results 24}

From the output obtained coefficient of determination (R2) of 0.614 , which contains the understanding that the variable $\mathrm{Y}$ is influenced by the variables $\mathrm{X} 1$ and $\mathrm{X} 2$ together equal to $61.4 \%$ while $38.6 \%$ influenced by other variables such as Brand Image, Brand Equity, Brand Awareness, Customer Satisfaction, Service Quality, Product Quality, and others.

TABLE VII. RESULTS OF ANOVA ANALYSIS VARIABLES X1 AND X2 TO VARIABLE Y

\begin{tabular}{ll|r|r|r|r|r}
\hline \multicolumn{8}{c}{ ANOVA $^{\mathbf{a}}$} \\
\hline \multirow{3}{*}{1} & Model & Sum of Squares & df & Mean Square & F & Sig. \\
& Regression & 3749.840 & 2 & 1874.920 & 263.861 & $.000^{\text {b }}$ \\
\cline { 2 - 8 } & Residual & 2359.097 & 332 & 7.106 & & \\
\hline & Total & 6108.937 & 334 & & & \\
\hline
\end{tabular}

a. Dependent Variable: Y_ALL

b. Predictors: (Constant), X2_ALL, X1_ALL

\section{Source: SPSS Processed Results 24}

The table explains whether there is a significant (significant) effect of the variable electronic word of mouth (X1) and the marketing mix (7P) (X2) on the Young Consumer Buy Interest variable (Y).

From the output it can be seen that $\mathrm{F}$ arithmetic $=263,861$ with level of significance $/$ probability $0.000<0,05$, then the regression model can be used to predict the Young Consumer Buying Interest variable. From table 4:22 it can be seen that simultaneously or together with variable of electronic word of mouth (X1) and marketing mix (7P) (X2) influence the young Consumer Buy Interest (Y) with significance $(\alpha)=5 \%$.

Multiple regression analysis is using $\mathrm{F}$ arithmetic. In this case, will be see whether a series of independent variables simultaneously affect the dependent variable. Significance is determined by comparing $\mathrm{F}_{\text {arithmetic }}$ with $\mathrm{F}_{\text {table. }}$.

To test the hypothesis:

If $\mathrm{F}$ arithmetic $<\mathrm{F}$ table: then $\mathrm{Ho}$ is accepted and $\mathrm{Ha}$ is rejected so that the variables $\mathrm{X} 1$ and $\mathrm{X} 2$ simultaneously do not affect the variable Y. 
If $\mathrm{F}$ arithmetic $>\mathrm{F}$ table: then $\mathrm{Ho}$ is rejected and $\mathrm{Ha}$ is accepted so that the variables $\mathrm{X} 1$ and $\mathrm{X} 2$ simultaneously affect the variable Y.

To find $\mathrm{F}$ table can use the following formula:

Number of samples which used $(n)=335$ and Number of variables $(k)=3$

The formula: $\quad \mathrm{df} 1=\mathrm{k}-1$, then $\mathrm{df} 1=3-1=2$

$$
\text { df } 2=\mathrm{n}-\mathrm{k} \text {, then } \mathrm{df} 2=335-3=332
$$

Since the test is done at $\alpha=5 \%$, then the value of $\mathrm{F}_{\text {table }}$ is 2,723 .

From Table ANOVA above can be seen with $F_{\text {arithmetic }}(263,861)>F_{\text {table }}(3,023)$.

TABLE VIII. RESULTS ANALYSIS OF VARIABLE COEFFICIENTS X1 AND X2 ON VARIABLE Y

\section{Coefficients $^{\text {a }}$}

\begin{tabular}{|c|c|c|c|c|c|c|c|c|}
\hline & \multirow[b]{2}{*}{ Model } & \multicolumn{2}{|c|}{$\begin{array}{l}\text { Unstandardized } \\
\text { Coefficients }\end{array}$} & \multirow{2}{*}{$\begin{array}{c}\text { Standardize } \\
\mathrm{d} \\
\text { Coefficients } \\
\text { Beta }\end{array}$} & \multirow[b]{2}{*}{$\mathrm{t}$} & \multirow[b]{2}{*}{ Sig. } & \multicolumn{2}{|c|}{$\begin{array}{l}\text { 95.0\% Confidence } \\
\text { Interval for B }\end{array}$} \\
\hline & & B & Std. Error & & & & $\begin{array}{l}\text { Lower } \\
\text { Bound }\end{array}$ & $\begin{array}{l}\text { Upper } \\
\text { Bound }\end{array}$ \\
\hline \multirow[t]{3}{*}{1} & (Constant) & .301 & .781 & & .385 & .700 & -1.236 & 1.838 \\
\hline & X1_ALL & .096 & .023 & .211 & 4.068 & .000 & .049 & .142 \\
\hline & X2_ALL & .108 & .009 & .612 & 11.771 & .000 & .090 & .126 \\
\hline
\end{tabular}

a. Dependent Variable: Y_ALL

\section{Source: SPSS Processed Results 24}

The table above shows a simple linear regression equation between electronic word of mouth variable (X1) and marketing mix (7P) (X2) to Consumer Buy Interest (Y) with the following equation:

$$
\mathrm{Y}=0,301+0,096 \mathrm{X} 1+0,108 \mathrm{X} 2
$$

From the result of the equation and result of previous analysis then got a result:

1. If the Electronic Word of Mouth variable increases 0.096 assuming the Marketing Mix (7P) variable is constant, it will be able to increase Consumer Buy Interest by 0,096 .

2. If the Marketing Mix (7P) variable increases by 0.108 assuming Electronic Word of Mouth variable is constant, it will be able to increase Consumer Buy Interest 0.108.

\section{CONCLUSIONS}

Based on the research discussion, it can be concluded that:

1. The effect of variable X1 (Electronic Word of Mouth) to variable Y (Consumer Interest) is $45.3 \%$.

2. The influence level of variable X2 (Marketing Mix (7P)) to variable Y (Consumer Buying Interest) is $59.5 \%$.

3. The influence level of variable X1 (Electronic Word of Mouth) and variable X2 (Marketing Mix (7P)) to variable Y (Consumer Buying Interest) is $61.4 \%$.

4. Based on the results of the analysis between variables $\mathrm{X} 1$ and $\mathrm{X} 2$ to variable $\mathrm{Y}$ it can be concluded that the marketing mix (7P) (X2) has a greater influence on young consumer buying interest $(\mathrm{Y})$ with an influence level of $59.5 \%$, greater influence than electronic wordof-mouth (X1) that affects the Y variable by $45.3 \%$.

\section{RECOMMENDATION}

The advice given by the author is as follows:

1. Future research objects may take the scope of other environments that may have characteristics similar to those of current research objects. It is recommended to be able to see the impacts generated in different locations and to prove existing theories about the research variables. 
2. In the next research it is suggested to be able to add other variables that may have a relation and influence on the dependent variable that exists. This is possible because the results of this study do not indicate the influence of $100 \%$ of any of the variables. With the addition of other variables it is possible to obtain a fixed model of factors that affect consumer buying interest.

3. From the results of descriptive statistical analysis had found 4 points that have the lowest value of each variable among others:

a. Statement 9 "Through Social Media, I can feel others want a restaurant / cafe to be successful". Mean: 4.19

Based on these results it is recommended to business owners to be more concerned about the effects of products and services provided so that consumers can feel a good experience and want the business to grow.

b. Statement 20 "Price is reachable by all circles". Mean: 4.05

Based on these results it is recommended to the business owner to be able to pay more attention to the existing market and based on these results it is advisable to the business owner to be able to pay more attention to the existing market and adjust the selling price with the average income and expenditure of existing consumers.

c. Statement 24 "Public transportation is sufficient to reach the Gading Serpong area". Mean: 4.01

Based on these results it is suggested to the local government or the developer of Gading Serpong area can add public transportation option to and from Gading Serpong.

d. Statement 43 "I am considering buying a restaurant / cafe product in the Gading Serpong area". Mean: 4.23

Based on these results it is advisable to business owners to be able to pay attention to all aspects that support consumer interest ranging from products, prices, services, and other aspects that may affect consumer interest to buy the product.

\section{REFERENCES}

Ajzen. I and M. Fishbein. (1975). Belief, Attitude, Intention and Behavior: An Introduction to theory and Research. Philippines: Addison-Wesley Publishing.

Assael, H. (1998). The consumer behavior and marketing action. Unites States. South-Western College publishing. pp.23-24.

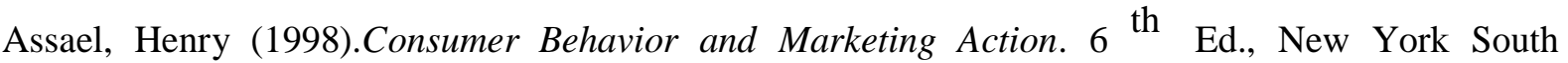
Western College Publishing

Badan Pusat Statistik (2016). Jumlah Kedatangan Wisatawan Mancanegara per Bulan ke Indonesia Menurut Pintu Masuk, (2008-2016). https://www.bps.go.id/linkTableDinamis/view/id/807 [20 Juli 2016]

Brotherton, B. (2008). Reseraching Hospitality and Tourism: A Student Guide. United States: SAGE.

Buchari, A. (2007), Manajemen Pemasaran \& Pemasaran Jasa. Bandung: Alfabeta.

Chen, L.D., et al. (2004). Consumer acceptance of virtual stores: a theoretical model and critical success factors for virtual stores. ACM Sigmis Database, 35(2), pp.8-31.

De Bruyn, A. \& Gary L. Lilien. (2008). A multi-stage model of word-of-mouth influence through viral marketing. International Journal of Research in Marketing, Elsevier. 25:151-163.

Evans, Dave. (2008). Social Media Marketing An Hour A Day. Canada: Wiley Publishing, Inc.

Ghozali, I. (2012). Aplikasi Analisis Multivariate dengan Program IBM SPSS 20. Semarang: Badan Penerbit - Universitas Diponegoro.

Gunelius, S. (2011). 30-minute Sosial Media Marketing. United States: McGraw-Hill Companies,Inc.

Hasan, A. (2010). Marketing dari Mulut ke Mulut. Yogyakarta: Media Pressindo.

Hendri, Muhammad Yusup, Yuliana Isma Graha (2007: 2) in Nurfitriani and Rumyeni (2016: 4), Pengaruh Social Media Marketing Melalui Official Account Line Alfamart Terhadap Minat Beli Konsumen. Jurnal Online Mahasiswa Bidang Ilmu Sosial dan Ilmu Politik Universitas Riau Volume 3 No. 2. 
Hennig-Thurau, T., et al. (2004). Electronic word-of-mouth via consumer-opinion platforms:What motivates consumers to articulate themselves on the Internet? Journal of Interactive Marketing, Elsevier. 18(1): 38-52.

Herr, P.M., et al. (1991). Effects of word-of-mouth and product-attribute information on persuasion: An accessibility-diagnosticity perspective. Journal of consumer research, 17(4), pp.454-462.

Husein, Umar. (2008). Metode Penelitian Untuk Skripsi dan Tesis Bisnis. Jakarta: PT Rajagrafindo Persada

Internet World Statistic (2017). Top Ten Internet Countries in Asia. www.internetworldstats.com/stats 3.htm [10 Feb 2017]

Jansen, B. J., et al. (2009). Twitter Power: Tweets as Electronic Word of Mouth. Journal of the American Society for Information Science and Technology, 60(11), pp.2169-2188.

Jeong, E. and SooCheongJang. (2011). Restaurant experiences triggering positive electronic word-ofmouth (eWOM) motivations. International Journal of Hospitality Management, 30(2), pp.356366.

Kotler, P. dan Gary Amstrong. (2004). Dasar-dasar Pemasaran, Edisi Kesembilan. Jakarta: PT. Indeks.

. (2012). Prinsip-prinsip Pemasaran, Edisi 13. Jilid 1. Jakarta: Erlangga.

Kotler, P. and Kevin Keller. (2012: 568), Marketing Management, $14^{\text {th }}$ Edition. Pearson Education Inc.

Kotler, P. and Kevin Keller. (2012: 568-570), Marketing Management, $14^{\text {th }}$ Edition. Pearson Education Inc. . (2009). Manajemen Pemasaran. Jilid I. Edisi ke 13. Jakarta: Erlangga. . (2012). Marketing Management. New Jersey: Pearson Education Limited.

Lupiyoadi, R. dan A. Hamdani. (2008). Manajemen Pemasaran Jasa Edisi 2. Jakarta: Salemba Empat.

Paramitha, Cindy Rizal Putri, (2011). Analisis Faktor Pengaruh Promosi Berbasis Sosial Media Terhadap Keputusan Pembelian Pelanggan dalam Bidang Kuliner. Thesis. Ekonomi S-1, Fakultas Ekonomi Universitas Dipenogoro.

Peter, J.P and Jerry C. Olson. (2010). Consumer Behavior and Marketing Strategy $9^{\text {th }}$ Edition. McGraw Hill Higher Education.

Puntoadi, Danis. (2011). Menciptakan Penjualan Melalui Social Media. Jakarta: PT Elex Komputindo.

Richins, Marsha L. and Teri Root-Shaffer. (1988). The Role of Evolvement and Opinion Leadership in Consumer Word-Of-Mouth: an Implicit Model Made Explicit. in NA - Advances in Consumer Research Volume 15, eds. Michael J. Houston, Provo, UT: Association for Consumer Research, Pages: 32-36.

Sands, S., et al. (2011). Customer-to-noncustomer interactions: Extending the 'social' dimension of the store environment. Journal of Retailing and Consumer Services, Elsevier. 37: 438-447.

Schiffman, L. G and Leslie Lazar Kanuk. (2008: 6). Consumer behavior. New Jersey: Prentice Hall International.

Septyanto, D. (2008). Pengukuran Variabel Dalam Peneltian. Universitas Indonesia Esa Unggul

Sernovitz. (2009). Word of Mouth Marketing. Jakarta: Gramedia Pustaka Utama.

Shankar, V., Smith, A. K., dan Rangaswamy, A. (2003). Customer Satisfaction and Loyalty in Online and Offline Environments. International Journal of Research in Marketing, 20 (2): 153-175.

Sugiyono. (2008). Metode Penelitian Kuantitatif Kualitatif dan R\&D. Bandung: Alfabeta (2012). Metode Penelitian Kuantitatif, Kualitatif, dan Kombinasi (Mixed Methods). Bandung: Alfabeta

Tahir, M. (2011). Pengantar Metodologi Penelitian Pendidikan. Makassar: Universitas Muhammadiyah Makassar

Zeithaml, V. \& Mary Jo Bitner. (2008). Service Marketing. Unites States: McGraw Hill Companies, Inc. 